\title{
Necrotizing of Cancer Cells is Possible through Drug Designing and Development
}

\author{
Wilson IB Onuigbo* \\ Department of Pathology, Medical Foundation and Clinic, Nigeria
}

Submission: April 25, 2017; Published: June 13, 2017

*Corresponding author: Wilson IB Onuigbo, Department of Pathology, Medical Foundation and Clinic 8 Nsukka Lane, Enugu 400001, Nigeria, Email: wilson.onuigbo@gmail.com

Abstract

The dictionary definition of "necrotizing" is causing or undergoing necrosis, a word said to have been first used in 1899. Historically, even before 1899, medical men and even cancer quacks had attempted to cure cancer with drugs. Nowadays, this is being intensified. Therefore, a personal hypothesis is proposed here with direct appeal to the recondite researchers in the fruitful field of drug designing and development..

Keywords: Cancer; Necrosis; Drug; Design; Thoracic duct; Research

\section{Introduction}

The Merriam-Webster's Collegiate Dictionary defines "necrotizing" as "causing or undergoing necrosis" [1]. It went on to indicate that this word was first used in 1899. However, before that year, causing necrosis was broadly the intention of the medical masters faced with cancer cases [2]. Nowadays, there is the hot pursuit for cure, this being aided by the mounting monetary means [3]. In this context, there is the fruitful front, namely, developing new targets for cancer treatment $[4,5]$. It is necessary, therefore, to direct attention to the status of the thoracic duct itself with a hypothesis.

\section{Hypothesis}

Historical attention was drawn to the premier position of the Pathology Laboratory at the Glasgow Western Infirmary [6]. As fate would have it, when the author trained there, he devised the Mono-Block Formalin-Method for investigating lung cancer [7]. Therefore, the obtained $45 \mathrm{~cm}$ long thoracic duct was coiled up in Swiss-roll fashion thereby facilitating its study in one microscope slide [8]. There upon, both lively cancer cells and dying cancer cells became research worthy. Indeed, the conclusion was clear thus: "Necrosis of the cancer cells was apparent in 3 cases, but it was clear that this had occurred in association with large aggregates of the malignant cells and that among each aggregated cells red blood corpuscles abounded." In effect, an erythrocyte associated necrosis factor (EANF) materialized naturally [9].

Accordingly, the vista has been opened for the microenvironment of the thoracic duct to be used jointly by researchers in the fields of (a) drug development and (b) those capable of cannulating this duct [10] and viewing it with the intra-vital video microscope [11]. Thereafter, there should be retrieval of the scientifically rich materials that pointedly embody necrosis. In conclusion, this hitherto hidden intrinsic Factor ought to surface from the recommended joint co-operative exercise. Furthermore, to confirm or confute the above hypothesis should resound profitably. In all probability, this envisaged breakthrough in target therapy could conduce to cancer cure.

\section{References}

1. Merriam Webster's Collegiate Dictionary. Springfield Mass: MerriamWebster, Inc., (12 ${ }^{\text {th }}$ edn), p. 829.

2. Onuigbo WIB (2009) Historical horizons of drug dispensing in cancer cases with hopeful hypothesis on cancer cure. J Coll Med 14(1): 1-5.

3. Woolf SH (2008) The meaning of translational research and why it matters. J Am Med Assoc 299(2): 211-213.

4. Curt GA (1996) Cancer drug development: New targets for cancer treatment. Oncologist 1(3): II-III.

5. Hait WN (2010) Anti cancer drug development: the grand challenges. Nat Rev Drug Discov 9(4): 253-254.

6. Lacyna LS (1988) The laboratory and the clinic: The impact of pathology on surgical diagnosis in the Glasgow Western Infirmary, 1875-1910. Bull Hist Med 62(3): 384-406.

7. Onuigbo WIB (1963) A mono-block formalin-fixation method for investigating cancer metastasis Z Krebsforsch 65: 209-210.

8. Onuigbo WIB (1967) The carriage of cancer cells by the thoracic duct. Br J Cancer 21(3): 496-500.

9. Onuigbo WIB (2013) Nature's necrosis factor when associated with erythrocytes may not only explain the surprises in lung cancer metastasis but also suggest target therapy. Med Hypotheses 80(6): 698-700. 
10. Mittleider D, Dykes TA, Cicuto KP, Amberson SM, Leusner CR, et al. (2008) Retrograde cannulation of the thoracic duct and embolization of the cisterna chyli in treatment of chylous ascities. J Vasc Intery Radiol 19(2 pt 1): 285-290.

This work is licensed under Creative

Commons Attribution 4.0 License

DOI: 10.19080/NAPDD.2017.01.555566
11. Chambers AF, MacDonald IC, Schmidt EE, Koop S, Morris VL, et al. (1995) Steps in tumor metastasis: new concepts from intravital videomicroscopy. Cancer Metastasis Rev 14(4): 279-302.

\section{Your next submission with Juniper Publishers will reach you the below assets}

- Quality Editorial service

- Swift Peer Review

- Reprints availability

- E-prints Service

- Manuscript Podcast for convenient understanding

- Global attainment for your research

- Manuscript accessibility in different formats

( Pdf, E-pub, Full Text, Audio)

- Unceasing customer service

Track the below URL for one-step submission https://juniperpublishers.com/online-submission.php 